\title{
Rural Credit Co-operatives: Significance, Challenges and the Road Ahead
}

\author{
M. M. Sury*
}

\begin{abstract}
Rural co-operatives form an integral part of the rural credit system in India. They are the main source of institutional credit to the farmers, and are chiefly responsible for breaking the monopoly of moneylenders in providing credit to the agriculturists. Despite the phenomenal outreach and volume of operations, the financial health of a very large proportion of rural credit co-operatives has deteriorated significantly. The institutions are beset with problems like low resource base, high dependence on external sources of funding, excessive governmental control, dual control, huge accumulated losses, imbalances, poor business diversification, low recovery etc. These institutions do not, therefore, inspire confidence among their existing and potential members, depositors, borrowers and lenders. Thus, there is a need to find ways for strengthening the cooperative movement and making it a well-managed and vibrant medium to serve the credit needs of rural India, especially the small and marginal farmers.
\end{abstract}

Keywords: Rural Credit Cooperatives; Institutional credit; Agriculture.

\subsection{Introduction}

India is a country with a population of 121 crore (2011 Census) of which around 70 percent resides in around 6 lakh villages. There are around 92,000 Primary Agricultural Credit Societies (PACS) in the country. On grounds of outreach, co-operatives cannot be ignored. The outreach is significant not merely in absolute numbers but also in terms of location of outlets. The number of PACS located in hilly terrains, deserts and other areas with poor access far exceed the number of rural branches of commercial banks and RRBs. Though the network of commercial banks and RRBs has spread rapidly, their reach in the countryside both in terms of the number of clients and accessibility to the small and marginal farmers and other poorer segments is far less than that of cooperatives.

**Formerly Economic Advisor - Delhi State Finance Commission, Formerly Reader, University of Delhi, Delhi (email: editorial@journalpressindia.com) 
62 | MANTHAN: Journal of Commerce and Management, Volume 3, Issue 2

The Government has taken many policy initiatives for strengthening farm credit delivery system for providing credit at affordable rates of interest to support the resource requirements of the agricultural sector. The emphasis of these initiatives has been on providing timely and adequate credit support to farmers with particular focus on small and marginal farmers and weaker sections of society to enable them to adopt modern technology and improved agricultural practices for increasing agricultural production and productivity. The policy essentially lays emphasis on augmenting credit flow at the ground level through credit planning, adoption of region specific strategies and rationalization of lending policies and procedures and bringing down the rate of interest on farm loan.

\subsection{Credit Needs of the Indian Farmers}

The need for agricultural credit arises because modern farm technology is costly and the personal resources of the farmers are inadequate. Provision of agricultural credit, as an input, is essential for widespread use of improved agricultural methods. Credit requirements of the farmers may be classified: (a) on the basis of purpose, and (b) on the basis of time. They need credit for productive as well as for unproductive purposes. Productive purposes include all such activities which help in the improvement of agricultural productivity such as purchase of inputs and permanent improvements in land. Unproductive credit needs include celebration of marriages and other social and religious functions and litigation.

Finance required for productive purposes can be divided broadly into the following categories:

- Short-term (for periods up to 15 months).

- Medium-term (from 15 months up to 5 years).

- Long-term (above 5 years).

Short-term loans are required for purchasing seeds, manures and fertilizers or for meeting labour charges etc. These are expected to be repaid after the harvest. Mediumterm loans are granted for purposes such as sinking of wells, purchase of bullocks, pumping plants and other improved implements etc. Loans repayable over a longer period (i.e. above 5 years) are classified as long-term loans. These are utilised for payment of old debts, purchase of the heavier machines, making permanent improvements and increasing the size of the holding.

\subsection{Sources of Credit for the Farmers}

The sources of credit for the poor can be grouped into two categories: (a) institutional sources, and (b) non-institutional sources. Institutional sources include co- 
operative societies, commercial banks and other government agencies. Non-institutional sources comprise moneylenders, landlords, relatives etc. A brief discussion on these sources is given below.

\subsection{Institutional sources}

The institutional sources of credit predominantly include the following:

a) Member-owned organisations: These include self-help groups, credit unions, and a variety of hybrid organizations like financial service associations. Like their informal cousins, they are generally small and local, which means they have access to good knowledge about each other's financial circumstances and can offer convenience and flexibility. Since they are managed by poor people, their costs of operation are low. However, these providers may have little financial skill and can run into trouble when the economy turns down or their operations become too complex. Unless they are effectively regulated and supervised, they can be captured by one or two influential leaders, and the members can lose their money.

b) Non-governmental organisations (NGOs): NGOs have spread around the developing world in the recent past. They have proven very innovative, with pioneering banking techniques like solidarity lending, village banking and mobile banking that have overcome barriers to serving poor populations. However, with boards that do not necessarily represent either their capital or their customers, their governance structures can be fragile, and they can become overly dependent on external donors.

c) Formal Financial Institutions: In addition to commercial banks, these include state banks, agricultural development banks, savings banks, rural banks and non-bank financial institutions. They are regulated and supervised, offer a wider range of financial services, and control a branch network that can extend across the country. However, they have proved reluctant to adopt social missions, and due to their high costs of operation, often cannot deliver services to poor or remote populations.

In India, agricultural credit is disbursed through a multi-agency network comprising of commercial banks, regional rural banks and co-operatives. With their vast network (covering almost all the villages in the country), wider coverage and outreach extending to the remotest part of country, the co-operative credit institutions, both in short and long-term structure are the main institutional mechanism for dispensation of agricultural credit.

Agricultural growth is crucial for alleviating rural poverty. Access to institutional credit to more farmers and appropriate quantity and quality of agricultural credit are crucial for realising the full potential of agriculture as a profitable activity. Provision of sufficient and timely credit at fair rates of interest has, therefore, to be considered as an integral part of 
agricultural development. Assistance rendered by way of credit has, however, to be related to specific items of productive work or of essential costs of cultivation.

\subsection{Non-institutional sources}

These include moneylenders, pawnbrokers, savings collectors, money-guards, input supply shops. Because they know each other well and live in the same community, they understand each other's financial circumstances and can offer very flexible, convenient and fast services. These services can also be costly and the choice of financial products limited and very short-term.

Till Independence in 1947, money lenders and the landlords were the principal sources of rural credit. Over the years, the operations of moneylenders have declined in view of debt relief legislations, the system of licensing moneylenders and restrictions on the use and transfer of land as security. Similarly, the abolition of all privileged tenures, both in zamindari and ryotwari areas, has discouraged investment by the landlords and larger cultivators.

Historically, moneylenders have played a significant role in meeting the credit needs of the rural producers. With stringent laws against money lending and the phenomenal growth of the formal credit delivery system, it was thought that money lenders would soon be out of business. Instead they have been in the business of lending in several disguises.

There are two types of moneylenders in rural areas: (a) agriculturist moneylenders who carry on the business of money lending along with farming, and (b) professional moneylenders whose only occupation is money lending. Although the relative importance of moneylenders has declined over the years, they are still an important source of credit for the rural people, particularly the small farmers and the artisans.

Moneylenders usually charge higher rates from poorer borrowers than from less poor ones. Moneylenders are popular because, unlike government agencies, they give credit for every purpose. They are easily approachable by the credit seekers and there are not many formalities in transacting a loan. However, the malpractices adopted by the moneylenders to exploit the needy farmers cannot be overlooked. These malpractices pertain to charging of high rate of interest and adopting unfair means in the maintenance of accounts.

Perhaps influenced by traditional Western views about usury, the role of the traditional moneylender has been subject to much criticism, especially in the early stages of modern micro finance. As more poor people gained access to loans from micro credit institutions, it became apparent that the services of moneylenders continued to be valued. Borrowers were prepared to pay very high interest rates for services like quick loan disbursement, 
confidentiality and flexible repayment schedules. They do not always see lower interest rates as adequate compensation for the costs of attending meetings, attending training courses to qualify for disbursements or making monthly collateral contributions. They also find it distasteful to be forced to pretend they were borrowing to start a business, when they were often borrowing for other reasons (such as paying for school fees, dealing with health costs or securing the family food supply). The more recent focus on inclusive financial systems affords moneylenders more legitimacy, arguing in favour of regulation and efforts to increase competition between them to expand the options available to poor people.

It is true that the institutional sources of credit have weakened the hold of moneylenders on the rural masses. However, the benefits of institutional credit have not percolated to all sections of rural population. Landless workers and marginal farmers have not benefited adequately due to their ignorance of new sources of credit and also on account of their weak repaying capacity. These underprivileged rural sections still depend on the moneylenders and suffer their exploitative practices.

\subsection{Co-operative Credit Societies}

These societies form an integral part of the rural credit system in India. They are the main source of institutional credit to the farmers. These societies are chiefly responsible for breaking the monopoly of moneylenders in providing credit to the agriculturists. There are around 1 lakh such societies in the country at present. In spite of their suitability and useful role in building up a just socio-economic rural life, co-operative societies suffer from various weaknesses. The heavy overdues of co-operative societies are a cause for concern. The rising overdues have reduced the borrowing and lending activities of these societies. Moreover, these societies have paid inadequate attention to the needs of landless workers and rural artisans. Influential people in the villages have been the main beneficiaries of co-operative credit. Of late, there has been a tendency on the part of political leadership to write-off loans of the farmers. The RBI has repeatedly expressed concern in this regard because non-repayment of loans by the existing borrowers can adversely affect recycling of funds and the credit chances of the prospective borrowers.

\subsection{Co-operative Banks}

Co-operative banks in India came into existence with the enactment of the Agricultural Credit Co-operative Societies Act in 1904. Co-operative banks form an integral part of the banking system in India. These banks operate mainly for the benefit of rural areas, particularly the agricultural sector. Co-operative banks mobilise deposits 
and supply agricultural and rural credit with a wider outreach. They are the main source of institutional credit to the farmers. Co-operative banks are chiefly responsible for breaking the monopoly of moneylenders in providing credit to agriculturists. They have also been an important instrument for various development schemes, particularly subsidy-based programmes for the poor. Co-operative banks operate for non-agricultural sector also but their role is small.

Though much smaller as compared to scheduled commercial banks, co-operative banks constitute an important segment of the Indian banking system. They have an extensive branch network and reach out to people in remote areas. They have traditionally played an important role in creating banking habits among the lower and middle-income groups and in strengthening the rural credit delivery system.

Unfortunately, financial reforms have not impacted the functioning of co-operative banks. This was brought out clearly in the following observation of the Reserve Bank of India, "Since the introduction of reforms, there has been very little perceptible improvement in either stability or efficiency of co-operative banks. In particular, the asset quality and profitability of scheduled urban co-operative banks (UCBs) showed some deterioration in the reform period. Positive impact of reforms, as has been witnessed in the case of commercial banking sector, may take longer to get manifested for co-operative banks given the late start of the reform process in this sector". (RBI, 2001-02)

The financial reforms process initiated in 1991 has tried to achieve regulatory convergence among various financial intermediaries in view of their systemic importance. Therefore, the basic objectives and instruments of reforms for co-operative banks have been the same as for state co-operative banks (SCBs). However, given the special characteristics of co-operative banks, they have been extended certain dispensations in terms of pace and sequencing of reforms.

The co-operative banking structure in India comprises urban co-operative banks and rural co-operative credit institutions. The Urban Co-operative Banks (UCBs) consist of a single tier, viz. primary co-operative banks, commonly referred to as urban co-operative banks. The Rural Credit Co-operatives have traditionally been bifurcated into two parallel wings: short-term and long-term, based on the nature of their lending operations.

\subsection{Rural Co-operatives}

\subsection{Short-term Rural Co-operatives}

The short-term rural co-operatives provide crop and other working capital loans to farmers and rural artisans primarily for short-term purposes. These credit institutions 
have a three-tier federal structure: (a) at the apex of the system is a state co-operative bank (SCB) in each State, (b) at the middle (or district) level, there are central cooperative banks (CCBs) also known as district co-operative banks, and (c) at the lowest (or village) level are the primary agricultural credit societies (PACS). The smaller States and Union Territories (UTs) have a two-tier structure with SCBs directly meeting the credit requirements of PACS.

a) State Co-operative Bank (SCB): SCB is the highest agency of the three-tier cooperative credit structure in a state. It serves as a link between RBI and the CCBs and PACS. The RBI provides credit to lower level co-operatives through the SCB. This function of the RBI has now been taken over by NABARD. The SCB also acts as a balancing centre for $\mathrm{CCBs}$ in the sense that surplus funds of some $\mathrm{CCBs}$ are made available to other needy CCBs. The SCB exercises general control and supervision over CCBs and PACS.

b) Central Co-operative Banks (CCBs): These banks act as a link between the SCB and the PACS. The main task of CCBs is to lend money to affiliated village primary societies. The CCBs are expected to attract deposits from the general public.

c) Primary Agricultural Credit Societies (PACS): These societies form the basic unit of the co-operative credit system in India. These voluntary societies based on the principle of one man one vote have posed challenge to the exploitative practices of the village moneylenders. The farmers and other small-time borrowers come in direct contact with these societies. The success of the co-operative credit movement depends largely on the strength of these village level societies. There are around 1 lakh such societies in the country at present. As a result of the expansion of the activities of PACS, the role of moneylenders in providing credit to agriculturists has decreased over the years. A major objective of PACS is to serve the needs of weaker sections of the society. For this purpose, the people with limited means, particularly scheduled castes and scheduled tribes, are encouraged to become members of these societies. Government has promoted multi-purpose societies in tribal areas for the benefit of people living there.

\subsection{Long-term Rural Co-operatives}

The long-term rural cooperatives provide typically medium and long-term loans for making investments in agriculture, rural industries and, in the recent period, housing. Generally, these co-operatives have two tiers, viz.: State Co-operative Agriculture and Rural Development Banks (SCARDBs), which operate at the State level; and Primary Co-operative Agriculture and Rural Development Banks (PCARDBs) that operate at the taluka/tehsil level. 


\subsection{Rural co-operatives: History and recent policy measures}

Rural credit co-operatives in India were originally envisaged as a mechanism for pooling the resources of people with small means and providing them with access to different financial services. Democratic in features, the movement was also an effective instrument for development of degraded waste lands, increasing productivity, providing food security, generating employment opportunities in rural areas and ensuring social and economic justice to the poor and vulnerable.

The history of the co-operative credit movement in India can be traced back to 1904 when the Co-operative Societies Act was passed. In 1919, co-operation became a provincial subject. The Co-operative Planning Committee, 1945 found that a large number of co-operatives were "saddled with the problem of frozen assets because of heavy overdues in repayment".

The co-operative banks in India play an important role in catering to the banking needs of the rural population. Soon after Independence in 1947, the inadequacy of rural credit engaged the attention of the Government of India and the RBI. The agricultural credit system as it has emerged over the years is the result of both evolution and intervention, and symbolises the nation's response to the dissatisfaction with the discredited colonial credit delivery system.

The Reserve Bank of India Act, 1934 has specific provisions relating to agricultural credit. Section 54 of the RBI Act specifically authorised the creation of an Agricultural Credit Department within the RBI to deal not only with the rural credit but also with the long-term finance including refinance. Section 17 of the Act empowered it to provide agricultural credit through state co-operative banks or any other banks engaged in the business of agricultural credit.

The foundation for building a broader credit infrastructure for rural credit was laid down by the All India Rural Credit Survey (1954). The Committee of Direction that conducted the survey recommended the creation of National Agricultural Credit Fund, which was subsequently created by the RBI. The Agricultural Refinance Corporation (ARC) set up by the RBI in 1963 provided funds by way of refinance, but credit cooperatives still did not function too well. Decentralised credit planning through the Lead Bank Scheme was also introduced to spearhead the credit allocation for, inter alia, agricultural lending. In order to emphasise the developmental and promotional role assigned to the ARC in addition to refinancing, the ARC was renamed as the Agricultural Refinance and Development Corporation (ARDC) in 1975.

Despite all these efforts, the flow of credit to the agricultural sector failed to exhibit any appreciable improvement as the co-operatives lacked resources to meet the expected demand. To solve these problems, the regional rural banks (RRBs) were set up in 1975. 
In order to strengthen the institutional credit for agriculture and rural development, National Bank for Agriculture and Rural Development (NABARD) was set up on July 12, 1982. On its establishment, NABARD took over the entire functions of the ARDC, the refinancing functions of the $\mathrm{RBI}$ in relation to co-operatives and regional rural banks (RRBs).

The rural credit co-operative system has served as an important instrument of credit delivery in rural and agricultural areas. The separate structure of rural co-operative sector for long-term and short-term loans has enabled these institutions to develop as specialised institutions for rural credit delivery. At the same time, their federal structure has helped in providing support structure for the guidance and critical financing for the lower structure. These institutions have wide outreach with as many as 92,432 primary agricultural co-operative societies (PACS), the grass root organisation of the rural cooperative banking structure, operating in the country at end-March 2012.

\subsection{Primary Agricultural Credit Societies (PACS)}

Primary agricultural credit societies (PACS) are the foundation of the co-operative credit system on which the superstructure of the short-term co-operative credit system rests. It is the PACS which directly interface with individual farmers, provide short-term and medium-term credit, supply agricultural inputs, distribute consumer articles and arrange for marketing of produce of its members through a co-operative marketing society.

PACS continue to rely heavily on external support and have not yet been able to become self-reliant in respect of resources through deposit mobilisation and internal accruals, affecting their growth and expansion of business activities.

PACS need to function as viable units responsive to the needs, aspirations and convenience of its members, particularly those belonging to the more vulnerable sections of the society. They must function effectively as well-managed and multi-purpose institutions mobilising the savings of the rural people and providing a package of services including credit, supply of agricultural inputs and implements, consumer goods, marketing services and technical guidance with focus on weaker sections.

Some of the critical challenges facing primary level co-operative credit institutions, apart from improving resource mobilisation, are the following.

- Increasing diversification in business portfolio.

- Improving volume of business.

- Arresting decline in membership by the borrowers.

- Reducing cost of management. 
- Correcting imbalances in loans outstanding.

- Improving skills of the staff and imparting professionalisation.

- Strengthening management information system (MIS).

- Reducing involvement in non/less profitable business.

\subsection{Problems of Rural Co-operatives}

Rural co-operatives form an integral part of the rural credit system in India. They are the main source of institutional credit to the farmers. These societies are chiefly responsible for breaking the monopoly of moneylenders in providing credit to the agriculturists. There are around 1 lakh such societies in the country at present.

Despite the phenomenal outreach and volume of operations, the financial health of a very large proportion of rural credit co-operatives has deteriorated significantly. The institutions are beset with problems like low resource base, high dependence on external sources of funding, excessive governmental control, dual control, huge accumulated losses, imbalances, poor business diversification, low recovery etc. These institutions do not, therefore, inspire confidence among their existing and potential members, depositors, borrowers and lenders. Thus, there is a need to find ways for strengthening the co-operative movement and making it a well-managed and vibrant medium to serve the credit needs of rural India, especially the small and marginal farmers.

Moreover, these societies have paid inadequate attention to the needs of landless workers and rural artisans. Influential people in the villages have been the main beneficiaries of co-operative credit. Of late, there has been a tendency on the part of political leadership to write-off loans of the farmers. The RBI has repeatedly expressed concern in this regard because non-repayment of loans by the existing borrowers can adversely affect recycling of funds and the credit chances of the prospective borrowers. A national approach on this issue is required so that co-operative credit system may fulfil the task assigned to it.

It is part of a historic policy infirmity which allowed co-operatives to be treated as refinance windows instead of incentivising them into becoming genuine thrift and credit institutions. The rural co-operative credit institutions are beset with many problems which include the following: low resource base, high dependence on refinancing agencies, lack of diversification, huge accumulated losses, persistent non-performing assets (NPAs), low recovery levels, and various other types of organisational weaknesses. NABARD and the RBI have been taking several supervisory and developmental measures in consultation with the Government of India for the revival of weak institutions and orderly growth of this important segment of the financial sector. 


\subsection{Task Force on Revival of Rural Co-operative Credit Institutions}

The Government of India had constituted this Task Force (Chairman: A. Vaidyanathan), 2005 to propose an action plan for reviving the rural co-operative banking institutions and suggest an appropriate regulatory framework for these institutions. The Task Force in its Report submitted to the Central Government on February 15, 2005 made several recommendations to strengthen the rural co-operative credit structure in the country.

The major recommendations of the Task Force were as under:

(i) Co-operative credit structure (CCS) is impaired in governance, managerial and financial fronts and hence needs to be revived and restructured.

(ii) Financial restructuring should be contingent on commitment to and implementation of legal and institutional reforms by the State Governments.

(iii) Financial assistance should be made available for: (a) wiping out accumulated losses, (b) covering invoked but unpaid guarantees given by the State Governments, (c) increasing the capital to a specified minimum level, (d) retiring Government share capital, and (e) technical assistance.

(iv) Availability of financial assistance from the Government of India should be strictly subject to legal and institutional reforms in the co-operative sector to ensure that the co-operatives become truly democratic and member-driven. These reforms should include: (a) ensuring full voting membership rights on all users of financial services including depositors, (b) removing state intervention in administrative and financial matters in co-operatives, (c) removing provision for Government equity and participation in the Boards of Co-operatives, (d) withdrawing restrictive orders on financial matters, and (e) permitting co-operatives the freedom to take loans from any financial institution and not necessarily from only the upper tier and similarly place their deposits with any financial institution of their choice.

(v) The Task Force also recommended certain major amendments to the provisions of the Banking Regulation Act, 1949 enabling removal of dual control and bringing the cooperatives under the regulatory control of the RBI. These included: (a) all co-operative banks should be on par with the commercial banks as far as regulatory norms are concerned (b) RBI should prescribe fit and proper criteria for election to the Boards of Co-operative Banks, (c) RBI should prescribe certain criteria for professionals to be on the Boards of Co-operative Banks, (d) CEOs of the co-operative banks should be appointed by the respective banks themselves, and (e) co-operatives, other than cooperative banks as approved by the RBI, should not accept non-voting member deposits. Such co-operatives should also not use words such as bank, banking, banker or any other derivative of the word bank in their registered name. 
72 | MANTHAN: Journal of Commerce and Management, Volume 3, Issue 2

(vi) Total financial assistance was estimated tentatively at Rs. 14,839 crore. The Task Force, however, recommended a special audit to ascertain the exact requirement of assistance. The financial assistance should be shared by the Government of India, State Governments and the CCS, based on the origin of losses within a flexible matrix.

(vii) NABARD should be designated as the nodal implementing and pass through agency to co-ordinate and monitor the progress of the programme representing the Government of India. NABARD should prepare model MoUs, model balance sheet proforma for PACS and CCBs.

\subsection{NABARD and the Co-operative Sector}

National Bank for Agriculture and Rural Development (NABARD) provides refinance to state co-operative agriculture and rural development banks (SCARDBs), state co-operative banks (SCBs), regional rural banks (RRBs) and other financial institutions approved by the RBI. The ultimate beneficiaries of refinance from NABARD could be individuals, partnership concerns, companies, State-owned corporations or cooperative societies.

\subsection{Credit extended by NABARD}

NABARD provides short-term credit facilities to SCBs in respect of eligible CCBs for purposes such as financing seasonal agricultural operations; marketing of crops; pisciculture activities; production and marketing activities of primary weavers/other industrial co-operative societies; labour contract/forest labour co-operative societies; individual rural artisans through PCS; procurement, stocking and distribution of chemical fertilisers; approved agricultural, allied and other marketing activities.

Besides short-term credit limits are also sanctioned to SCBs on behalf of apex/regional weavers/other industrial societies for financing procurement and marketing and trading-in-yarn. Short-term limits are also provided to RRBs for financing seasonal agricultural operations, marketing of crops and pisciculture activities. Mediumterm facilities are also provided to SCBs and RRBs for converting short-term into medium-term loans and for approved agricultural investments. Long-term loans are provided to the State Governments for contributing to the share capital of co-operative credit institutions.

In pursuance of the announcement made by the Finance Minister in June 2004 for enhancing the credit flow to the agriculture sector, NABARD advised SCBs, CCBs and RRBs on the measures to be taken under various schemes to give relief to farmers. It was 
apprehended that the implementation of these measures coupled with providing conversion/rescheduled loans to farmers may result in a liquidity problem for cooperative banks and RRBs, impairing their ability to provide fresh loans and achieve the desired growth rate during the year. In order to mitigate this, NABARD introduced a liquidity support scheme during 2004-05 for these institutions. SCBs were sanctioned a liquidity support of Rs. 1,770 crore during 2004-05. NABARD also sanctioned longterm loans to 9 State Governments amounting to Rs. 39 crore as contribution to the share capital of co-operative credit institutions.

\subsection{Advisory Committee on the Flow of Credit to Agriculture and Related Activities from the Banking System, 2004}

As indicated in its mid-term review of November, 2003, the RBI constituted an Advisory Committee on flow of Credit to Agriculture and Related Activities from the Banking System (Chairman: V.S. Vyas). The Advisory Committee submitted its interim report in April, 2004 and the final report in June, 2004. Some of the major recommendations of the Committee are as follows:

(i) A review of mandatory lending to agriculture by commercial banks to enlarge direct lending programmes.

(ii) Public and private sector banks to increase their direct agricultural lending to 12 percent of net bank credit in the next two years and to 13.5 percent two years thereafter, within the overall limit of 18.0 percent of total agricultural lending.

(iii) Banks to increase their disbursements to small and marginal farmers under Special Agricultural Credit Plan (SACP) to 40 percent by March 2007.

(iv) SACP to be restricted to direct lending and extended to private sector banks.

(v) Reduction in cost of agricultural credit by enhancing the cost effectiveness of agricultural loans.

(vi) NPA norms for agricultural credit to be aligned with crop seasons. Loans for allied activities to be classified as NPA after 180 days of default. Credit flow to small borrowers to be improved through reduction in cost of borrowing, revolving credit packages, procedural simplification, involvement of panchayati raj institutions (PRIs) and micro finance.

(vii) The SAA to be modified to remove rigidities. SAA to be mandatory only for Government sponsored programmes and the format of village surveys to be changed in view of current realities.

Based on the recommendations contained in the interim report of the Vyas Committee, the RBI, in its annual policy statement for 2004-05, announced a number of 
measures to improve credit delivery to agriculture. These included, treating loans to storage units designed to store agricultural products, irrespective of location, as indirect credit to agriculture, treating investment by banks in securitised assets representing direct (indirect) lending to agriculture as direct (indirect) lending to agriculture, and waiver of margin/security requirement for agricultural loans up to Rs. 50,000 and in case of agribusiness and agri-clinics for loans up to Rs. 5 lakh. In addition, RBI also aligned repayment dates with harvesting of crops by treating loans granted for short duration crops as an NPA, if the instalment of the principal or interest thereon remains unpaid for two crop seasons beyond the due date. Loans granted for long duration crops are treated as an NPA, only if the instalment of the principal or interest thereon remains unpaid for one crop season beyond the due date.

As recommended by the Vyas Committee, RBI announced that microfinance institutions would not be permitted to accept public deposits, unless they comply with the extant regulatory framework. The recommendation relating to service area approach (SAA) was accepted and an announcement to this effect was made in the RBI's midterm review of annual policy statement for 2004-05.

Most of the PSBs, co-operative banks and RRBs had reduced the rate of interest on farm loans up to Rs. 50,000 to 9.0 percent and, in some cases, to 8.5 percent. This has enabled the farmers to derive the benefit of falling interest rates and to improve their margins on farming and allied operations. Also, as a measure to minimise the incidence of under-financing, the scale of finance for crop loans and unit costs of farm investments have been further revised and made more realistic in the current year. Furthermore, to mitigate the risk of agriculture arising out of drought conditions, banks either postponed the recovery of loans or converted short-term credit into medium-term credit with appropriate rescheduling in repayment in the concerned areas. The norms of financing in the Rabi season have been liberalised taking into account the likely shortfall in Kharif output on account of deficient rainfall.

In connection with the implementation of the recommendations of the Vyas Committee, the Economic Survey, 2005-06 observed, "Continuing its endeavour to enhance the flow of credit to agriculture by removing delivery bottlenecks, the RBI, together with NABARD, implemented most of the recommendations of the Advisory Committee on Flow of Credit to Agriculture and Related Activities from the Banking System (Chairman: V.S. Vyas). Out of 99 recommendations made by the Committee, 33 were accepted and implemented by October 2005. These related to the following matters.

- Procedural modifications and rationalisation of systems and procedures.

- Tie-ups with related farm machinery manufacturers by banks. 
- Co-opting joint liability group (JLG) and self-help group (SHG) approaches in addressing issues relating to financing oral lessees.

- Addressing delays/refusal in opening savings bank accounts of SHGs.

- Improving staffing in the rural areas to promote retail lending to agriculture.

- Use of individual volunteers, farmers' clubs or NGOs/SHGs as direct selling agents.

- Building synergy between good working primary agricultural credit societies and commercial banks.

- Use of IT in rural branches.

- Working out appropriate incentive structure for prompt repayment.

- Making the rates of interest on small loans reasonable.

- Improving the efficiency of credit delivery to small borrowers and association with contract farming.

\subsection{Expert Group on Investment Credit in Agriculture, 2005}

With a view to increasing the flow of credit to agriculture, the RBI set up this Expert Group (Chairman: Y.S.P. Thorat) to formulate a strategy for increasing investment credit in agriculture. The Group in its Report submitted in June 2005 identified several factors which constrain growth in investment in agriculture. These included meagre growth in minor irrigation and farm mechanization; declining public sector investment; limited credit absorptive capacity; lack of effective mechanism for technology transfer and poor extension services; limited infrastructure for agro processing, storage, warehousing, value addition and marketing; restrictions on purchases outside the mandis; weather aberrations and output price fluctuations; inadequate risk mitigation mechanism; and non-availability of land records.

The Group emphasised the need to accelerate investment in agriculture in order to achieve the desired level of growth. It also highlighted the need for investments to be appropriately structured, timed and well implemented in order to attain maximum effectiveness. The major recommendations of the Group are set out below.

(i) In view of various changes in the Indian rural canvas over the past few years, there is need for a shift in the thrust areas for investment credit to agriculture. Apart from the traditional investments such as land development and irrigation, increased focus needs to be accorded to the entire supply chain management of agriculture products, reform of agriculture markets and public management in agricultural infrastructure.

(ii) State Governments need to lay emphasis on legal provisions/computerisation of land records, legal support for recovery, reforms in agricultural marketing, improving 
credit absorptive capacity through supporting infrastructure, strengthening infrastructure, improving extension network and developing marketing links.

(iii) NABARD should take special steps to facilitate capacity building of credit institutions in appraisal skill, particularly in North Eastern States, and design appropriate products for financing rural infrastructure projects outside the RIDF by mobilising resources from the market or banks at competitive rates of interest.

(iv) Water management policies and investment in water conservation be designed jointly by the State Governments and banks for improving productivity in agriculture.

(v) The State Governments and NABARD should make investments in participatory community projects and in soil treatment to make wasteland and fallow land cultivable.

(vi) With a view to strengthening the institutional credit mechanism, short-term credit be integrated with term credit and efforts be made to reach the 'unreached' areas, promote supplementary credit delivery channels, outsource monitoring services, provide loan support for diversified agriculture, review HR policies, share the pool of technical expertise and make use of the model bankable projects prepared by NABARD.

(vii) The RBI along with banks could adopt agency models for credit delivery.

(viii) Government of India/State Governments and organisations engaged in agricultural research and development (R\&D) to reorient $R \& D$ activities.

(ix) To mitigate the risk in financing of agriculture, the Group suggested several measures such as developing suitable financial products and commodity exchanges; allowing banks to operate on behalf of farmers and participate in commodity futures; establishing a risk fund for fragile agriculture; designing special risk mitigation packages for low asset-based borrowers; using warehousing receipts with price hedging instruments; adopting technology for dissemination of market intelligence; sharing borrower information; and financing value chain by banks/through RIDF.

\subsection{Regulatory Framework and Supervision}

\subsection{Additional provisioning requirement for NPAs}

For the sake of convergence in policies governing all banks, guidelines for additional provisioning for all advances classified as doubtful for more than three years were issued on March 1, 2005, to be implemented in a phased manner from April 1, 2007. In terms of the guidelines, for the unsecured portion of the advance, which is not covered by the 
realisable value of tangible security to which the bank has a valid recourse and the realisable value is estimated on a realistic basis, provision will be to the extent of 100 percent, as hitherto. The secured portion, on the other hand, would be divided into two categories. Outstanding stock of NPAs classified as doubtful for more than three years as on March 31, 2007 would need to be provided for in a phased manner up to 100 percent till March 31, 2010. Also, 100 percent provisioning would need to be made for the advances classified as doubtful for more than three years on or after April 1, 2007.

\subsection{Prudential guidelines on agricultural advances}

As mentioned in the Annual Policy Statement of the RBI for the year 2004-05, prudential norms on income recognition, asset classification and provisioning with respect to agricultural advances were modified on July 12, 2004 with a view to aligning the repayment dates with harvesting of crops. Accordingly, effective September 30, 2004 a loan granted for short duration crops is required to be treated as NPA if the instalment of the principal or interest thereon remains unpaid for two crop seasons beyond the due date. A loan granted for long duration (with crop season longer than one year) crops is required to be treated as NPA, if the instalment of principal or interest thereon remains unpaid for one crop season beyond the due date.

\subsection{Asset classification for State Government Guaranteed Advances}

Revised guidelines on asset classification norms for State Government guaranteed exposures (i.e. advances and investments), as applicable to commercial banks, were issued to SCBs and CCBs on January 20, 2005 which are to be implemented in a phased manner. Accordingly, it was decided to delink the asset classification and provisioning requirements in respect of State Government guaranteed loans and advances from invocation of State Government guarantee and treat such exposures for asset classification purpose in the same manner as applicable to exposures not guaranteed by the State Governments. However, with a view to enabling banks to have a smooth transition in the matter, the revised prudential norms in respect of State Government guaranteed exposures (i.e. both advances and investments) will be implemented in a phased manner in two stages.

With effect from the year ending March 31, 2006, State Government guaranteed advances and investments in State Government guaranteed securities would attract asset classification and provisioning norms, if interest and/or instalment of principal or any other amount due to the bank remains overdue for more than 180 days. In the second stage, which would begin from the year ending March 31, 2007, State Government guaranteed advance and investment in State Government guaranteed securities would attract asset classification and provisioning norms, if interest and/or instalment of 
principal or any other amount due to the bank remains overdue for more than 90 days.

\subsection{Inspections}

NABARD undertakes inspection of RRBs, SCBs and CCBs in accordance with the powers vested under Section 35(6) of the Banking Regulation Act, 1949 (AACS). Besides, NABARD conducts voluntary inspection of SCARDBs, Apex Weavers' Cooperative Societies and State Co-operative Marketing Federations. The frequency of statutory/voluntary inspections by NABARD was increased from 2005-06. The statutory inspections of CCBs and RRBs with positive net worth as also the voluntary inspections of Apex Co-operative Societies/Federations would continue to be conducted once in two years. With the introduction of annual inspections, the system of conducting quick inspections has been dispensed with.

The Board of Supervision (BoS) constituted by NABARD in 1999 to provide guidance and direction on matters relating to supervision of SCBs, CCBs and RRBs meets periodically and deliberates on such issues as review of insolvent SCBs and CCBs; state-wise review of the functioning of co-operative credit institutions; review of off-site supervisory system (OSS); review of frauds, misappropriation, embezzlements, and defalcations; procedure for receipt and follow-up of compliance reports on inspection findings; risk management systems in co-operative banks and RRBs; and review of financial position of RRBs with deposit erosion of 25 percent or more.

The Board has often expressed concern over: (a) deterioration in the financial position of many co-operative banks, (b) non-compliance by several banks with the provisions of Section 11(1) of the Banking Regulation Act, 1949 (AACS), relating to minimum capital requirement, and (c) absence of penal provision against the banks not adhering to the RBI's guidelines for asset classification and provisioning norms.

\subsection{Problem of Triangular Regulation of Rural Co-operatives}

In the case of the rural banking sector, apart from the presence of the Registrar of Cooperative Societies for incorporation/registration-related regulation, banking regulation is further split between the RBI, which has the regulatory powers, and NABARD which is vested with the supervisory responsibility. The shortcomings of this segregation of regulatory and supervisory roles is compounded by the fact that NABARD has limited powers of enforcement of its supervisory findings, for which it has to depend on either its own persuasiveness or seek action through interventions by the RBI or the State Government.

The duality of control over the co-operative institutions is a contentious issue. The Task Force on Co-operative Credit System (Chairman: Jagdish Capoor), 1999 addressed 
the issue of duality of control over co-operative credit institutions and suggested to remove the overlap of controls and endowing functional autonomy and operational freedom to co-operatives. The Task Force suggested to draw an Action Plan to redefine the roles and responsibilities and areas of regulation through delegation of powers in respect of all the players in the field, viz. the State Government, RBI, NABARD and cooperative institutions. In view of the weaknesses persisting in the co-operative banks, a system of preparation of institution-specific development action plans and execution of Memorandum of Understanding have been initiated since 2003-04.

\subsection{Agricultural Credit: Recent Policy Announcements}

Concerned over the slower growth of agriculture credit, the Government announced a comprehensive policy on June 18,2004 . The policy envisaged a 30 percent increase in credit to agriculture sector in 2004-05 over an estimated credit flow of Rs. 80,000 crore in 2003-04. The implementation of the policy was entrusted to public sector banks, private sector banks, regional rural banks (RRBs) and co-operative banks. The policy indicated that each rural and semi-urban branch of commercial banks, on an average, would take up at least two to three new investment projects in the area of plantation and horticulture, fisheries, organic farming, agro-processing, livestock, micro irrigation, sprinkler irrigation, watershed management, village pond development and other agricultural activities. NABARD was asked to advise District Level Technical Committees to review the scales of finance to meet the realistic credit needs of farmers, especially for capital intensive agricultural operations.

The Budget for 2004-05, presented in the Parliament on July 8, 2004, proposed doubling of credit to agriculture in three years and announced further measures to achieve the target growth in agricultural credit. These measures included holding the sponsor bank of each RRB squarely responsible for the performance of RRB under its control and an incentive scheme under which RRBs, adopting new governance standards and abiding by prudential regulations, qualified for receiving funds from the Government for their restructuring. The Budget proposed setting up of a Task Force to examine the reforms required in the co-operative banking system including the appropriate regulatory regime.

Consequent upon above mentioned policy measures, the flow of institutional credit to the agricultural sector has increased significantly in recent years (Table 1).

\subsection{Agricultural Debt Waiver and Debt Relief Scheme, 2008}

In the wake of suicides by farmers in some parts of the country, indebtedness of 
the farmers was high on the agenda of the Government. The Government had appointed a Committee (Chairman: R. Radhakrishna) to examine all aspects of agricultural indebtedness. The Committee in its report made a number of recommendations but stopped short of recommending waiver of agricultural loans.

Table 1: Flow of Institutional Credit to Agriculture and Allied Activities

(Rs. crore)

\begin{tabular}{|l|r|r|r|r|r|}
\hline Agency & \multicolumn{1}{|c|}{$\mathbf{2 0 0 8 - 0 9}$} & $\mathbf{2 0 0 9 - 1 0}$ & $\mathbf{2 0 1 0 - 1 1}$ & $\mathbf{2 0 1 1 - 1 2}^{\wedge}$ & $\mathbf{2 0 1 2 - 1 3}^{*}$ \\
\hline Co-operative & 46,192 & 63,497 & 78,121 & 87,963 & 64,664 \\
Banks & $(15)$ & $(17)$ & $(17)$ & $(17)$ & $(27)$ \\
\hline Regional Rural & 26,765 & 35,218 & 44,293 & 54,450 & 32,127 \\
Banks & $(9)$ & $(9)$ & $(10)$ & $(11)$ & $(13)$ \\
\hline Commercial Banks & $2,28,951$ & $2,85,799$ & $3,45,877$ & $3,68,616$ & $1,42,838$ \\
& $(76)$ & $(74)$ & $(74)$ & $(72)$ & $(60)$ \\
\hline Total & $3,01,908$ & $3,84,514$ & $4,68,291$ & $5,11,029$ & $2,39,629$ \\
\hline
\end{tabular}

$\wedge$ Provisional; * Up to September 2012

Figures in parentheses indicate percentage of total flow of institutional credit.

Source: Government of India, Economic Survey, 2012-13, p. 111, Table 5.7.

However, Government was conscious of the problems being faced by the farmers, especially the small and marginal farmers. Having carefully weighed the pros and cons of debt waiver and having taken into account the resource position, the Finance Minister announced the following scheme of debt waiver and debt relief for farmers:

(i) All agricultural loans disbursed by scheduled commercial banks, regional rural banks and cooperative credit institutions up to March 31, 2007 and overdue as on December 31, 2007 were covered under the scheme.

(ii) For marginal farmers (i.e. holding up to 1 hectare) and small farmers (1-2 hectare), there was a complete waiver of all loans that were overdue on December 31, 2007 and which remained unpaid until February 29, 2008. In respect of other farmers, there was a one time settlement (OTS) scheme for all loans that were overdue on December 31, 2007 and which remained unpaid until February 29, 2008. Under the OTS, a rebate of 25 percent was given against payment of the balance of 75 percent.

(iii) Agricultural loans were restructured and rescheduled by banks in 2004 and 2006 through special packages. These rescheduled loans, and other loans rescheduled in the normal course as per RBI guidelines, were also eligible either for a waiver or an OTS on the same pattern.

(iv) The implementation of the debt waiver and debt relief scheme was to be completed 
by June 30, 2008. Upon being granted debt waiver or signing an agreement for debt relief under the OTS, the farmer was entitled to fresh agricultural loans from the banks in accordance with normal rules.

(v) Government estimated that about 3 crore small and marginal farmers and about 1 crore other farmers would benefit from the scheme. The total value of overdue loans waived was estimated at Rs. 50,000 crore and the OTS relief on the overdue loans at Rs. 10,000 crore.

\subsection{Conclusion}

To sum up, historically, rural co-operative credit institutions (or simply rural cooperatives) have played an important role in providing institutional credit to the agricultural and rural sectors. The structure of rural co-operative banks is not uniform across all the States of the country. Some States have a unitary structure with the State level banks operating through their own branches, while others have a mixed structure incorporating both unitary and federal systems.

Rural indebtedness is noted as a major reason for the spurt in farmer suicides during recent times across a number of states. In most, if not all, such cases, the economic status of the suicide victim was very poor, being small and marginal farmers. After the Green Revolution, agricultural activities have become cash-based individual enterprises requiring high investment in modern inputs and wage labour. This is evident from the list of states with high incidence of farmer suicides, which are not necessarily backward or predominantly agrarian or with low income. Increased liberalisation and globalisation have in fact led to a shift in cropping pattern from staple crops to cash crops like oilseeds and cotton, requiring high investment in modern inputs and wage labour, and increasing credit needs but when the prices decline farmers have no means to supplement their incomes.

In spite of their suitability and useful role in building up a just socio-economic rural life, co-operative societies suffer from various weaknesses and their performance has been far from satisfactory in certain respects. The heavy overdues of co-operative societies are a cause for concern. The rising overdues have reduced the borrowing and lending activities of these societies. The increasing incidence of defaulting has brought bad name to these societies.

Co-operative societies have paid inadequate attention to the needs of landless workers and the rural artisans. The influential people in the villages have been the main beneficiaries of co-operative credit. Of late, there has been a tendency on the part of political leadership to write off the loans of the farmers. The RBI has repeatedly 
expressed concern in this regard because the non-repayment of loans by the existing borrowers adversely affects recycling of funds and the credit chances of prospective borrowers. A national approach on this issue is required so that co-operative credit system may fulfil the task assigned to it.

Positive impact of reforms, as has been witnessed in the case of commercial banking sector, may take longer to get manifested for co-operative banks given the late start of the reform process in this sector. Unless such a positive scenario evolves for the cooperative banking sector in the near future, the financial health of many of these banks would continue to remain a cause of concern.

It is imperative that the government takes initiatives to expand the network of institutional credit facilities in the rural areas and that the credit needs of the small and marginal farmers are met through earmarking credit for the group. Extension and marketing initiatives need to focus on this segment. At the same time, group initiatives need to be encouraged and awareness among the group has to be increased. The procedural formalities also have to be made less stringent to make the system more userfriendly for the largely illiterate group.

Given the distress among the farmers, it is important that a safety-net programme is introduced to ensure a minimum income for the farmers. Also the risk factor has to be mitigated through adequate insurance and credit facilities. At the same time, the outreach and efficiency of the institutional credit sources have to be improved. This is important to protect the small and marginal farmers who still heavily rely on private moneylenders who charge high interest rates and follow unscrupulous means to perpetuate indebtedness.

\section{References}

Basu, Priya. (2005). A financial system for India's poor. Economic and Political Weekly, 37.

Beatrize, Armendariz \& Morduch, Jonathan. (2007). Economics of Microfinance. Prentice Hall of India Pvt. Ltd.

Bhatt, Nitin \& Thorat, Y.S.P. (2001). India's Regional Rural Banks: The institutional dimension of reforms. Journal of Microfinance, 3(1).

Chattopadhyay, S.K. (2010), RBI Working Paper on Financial Inclusion in India: A Case Study of West Bengal, Working Paper Series 8-10, September, RBI. 
Government of India (2005-06). Economic Survey, 2005-06.

Rajaraman, Indira. (2005). Financing rural infrastructure in developing countries. Applied Econometrics and International Development, 5.

Rao, K.S. (2009). Micro credit engine for inclusive growth. The Indian Banker, September, 4(9): 40-43.

Reserve Bank of India (2001-02). Report on Currency and Finance, 2001-2002, p. VI18.

Sarkar, A.N. \& Singh, Jagjit. (2006). Savings-led micro finance to bank the unbankables: Sharing of global experience. Global Economic Review, 7(2).

Sarma, M. (2008). Index of Financial Inclusion. ICRIER Working Paper, August. 